\title{
Mapping the interactome of overexpressed RAF kinase inhibitor protein in a gastric cancer cell line
}

\author{
Huan Gu', Xianquan Zhan², Guiying Zhang ${ }^{1 *}$, Lu Yan', William CS Cho ${ }^{3}$, Maoyu Li², Ting Liu' and Zhuchu Chen²
}

\begin{abstract}
Background: Gastric cancer (GC) is a threat to human health with increasing incidence and mortality worldwide. Down-regulation or absence of RAF kinase inhibitor protein (RKIP) was associated with the occurrence, differentiation, invasion, and metastasis of GC. This study aims to investigate the molecular mechanisms and biological functions of RKIP in the GC biology.

Methods: The fusion expression plasmid pcDNA3.1-RKIP-3xFLAG was transfected into SGC7901 cells, the RKIP fusion proteins were purified with anti-flag M2 magnetic beads, and the RKIP-interacting proteins were identified with tandem mass spectrometry (MS/MS), and were analyzed with bioinformatics tools. Western blot and co-immunoprecipitation were used to confirm the interaction complex.
\end{abstract}

Results: A total of 72 RKIP-interacting proteins were identified by MS/MS. Those proteins play roles in enzyme metabolism, molecular chaperoning, biological oxidation, cytoskeleton organization, signal transduction, and enzymolysis. Three RKIP-interaction protein network diagrams were constructed with Michigan Molecular Interactions, functional linage network, and Predictome analysis to address the molecular pathways of the functional activity of RKIP. The MS/MS-characterized components of the existing interaction complex (RKIP, HSP90, 14-3-3ع, and keratin 8) were confirmed by Western blot analysis and co-immunoprecipitation.

Conclusion: This study is the first discovery of the interaction of RKIP with HSP90, 14-3-3, and keratin. The present data would provide insight into the molecular mechanisms of how RKIP inhibits the occurrence and development of GC.

Keywords: Affinity chromatography, Co-immunoprecipitation, Fusion protein expression, Gastric cancer, RAF kinase inhibitor protein (RKIP), Tandem mass spectrometry

\section{Background}

The incidence of gastric cancer (GC) ranks fourth among cancers in the world, and its incidence and mortality rank second among malignant tumors of the digestive tract $[1,2]$. A total of 750,000 patients die from GC each year in the world, including 160,000 patients in China [1]. The pathogenesis of GC still remains unclear. Early gastric diagnosis, the prediction of relapse and metastasis, and prognosis assessment are of importance for GC prevention. Therefore, searching for new tumor markers and gene therapy targets is of high priority.

\footnotetext{
* Correspondence: guiyingzhang@hotmail.com; yjzhan2011@gmail.com ${ }^{2}$ Key Laboratory of Cancer Proteomics of Chinese Ministry of Health, Xiangya Hospital, Central South University, Changsha, Hunan 410008, China 'Department of Gastroenterology, Xiangya Hospital, Central South University, Changsha, Hunan 410008, China

Full list of author information is available at the end of the article
}

Our previous laser-capture microdissection (LCM)based quantitative proteomics studies found that RAF kinase inhibitor protein (RKIP) was significantly downregulated in the GC tissues compared with the normal gastric mucosa tissues [3,4]. RKIP is a small $(21 \mathrm{kDa})$, highly conserved cytoplasmic protein, and is a member of the phosphate ester acyl diethanolamine-binding protein family that participates in lipid metabolism and phospholipid membrane formation [5]. RKIP is extensively expressed in a variety of tissues and different cell types with multiple physiological and pathological functions [5]. The abnormal expression of RKIP plays an important role in the growth and differentiation process of GC [6] with evidences that a positive correlation between RKIP expression and the degree of differentiation of the GC tissue and a negative correlation between RKIP expression and tumor infiltration depth, TNM staging, and lymph

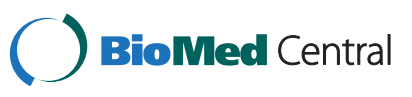

(c) 2013 Gu et al.; licensee BioMed Central Ltd. This is an open access article distributed under the terms of the Creative Commons Attribution License (http://creativecommons.org/licenses/by/2.0), which permits unrestricted use, distribution, and reproduction in any medium, provided the original work is properly cited. 
node metastasis were found by immunohistochemistry and Western blot analyses $[3,4]$.

Moreover, many studies have demonstrated a negative correlation between RKIP protein and the metastatic ability of malignant tumors such as prostate cancer, breast cancer, colon cancer, melanoma, and adenocarcinoma, as well as the potential anti-cancer activity of RKIP protein, which would be a novel therapeutic target for cancer [7-14]. Besides, RKIP protein can promote the apoptosis of tumor cells. It was reported that after treatment with chemotherapy drugs, breast cancer and prostate cancer cells can induce RKIP protein expression and cell apoptosis [15]. The decreased expression of RKIP in breast cancer cells and prostate cancer cells inhibits chemotherapy-induced apoptosis, whereas the restoration of RKIP expression can increase the sensitivity of the tumor cells to chemotherapy drugs [15]. The loss of abnormally expressed RKIP functions increases the resistance of cancer cells to chemotherapy, which causes the growth of the tumor cells [12]. Therefore, the down-regulation or absence of RKIP expression plays an important role in the development of tumors.

Study found that RKIP interacts with a number of different proteins and regulates multiple signaling pathways $[16,17]$. However, the molecular mechanisms, biological functions, and the interacted proteins of RKIP inhibiting the occurrence and metastasis of GC remain unclear. Targeted proteomics is an effective approach for investigating the molecular mechanisms and biological functions of a given protein that is associated with a disease. Meanwhile, the 3xFLAG system coupled with highly specific and sensitive anti-FLAG antibodies is an effective and optimized approach for detection of fusion protein and its interacting proteins [18-20], and has successfully used to study the PPP1CC2-interacting proteins in transgenic mouse embryonic stem cells [21], NLRC4 phosphorylation [22], BAP1-interacting proteins [23], HMGB1interacting proteins [24], FAT10-interacting proteins [25], and CyaA-interacting proteins [26]. In this study, the targeted proteomic strategy combined 3xFLAG-based affinity purification and tandem mass spectrometry to isolate and identify the RKIP-related proteins from the RKIPoverexpressed SGC7901 GC cell line (Figure 1). This study would provide insight into the molecular mechanisms of how RKIP inhibits the occurrence and development of GC.

\section{Methods}

\section{Instruments and software}

IPGphor, Ettan DALT II System, Image-Scanner (maximum resolution 9,600 ×9,600 dpi; Amersham Biosciences, Stockholm, Sweden), electrospray ionization-quadrupoletime of flight (ESI-Q-TOF) Mass Spectrometer (Micromass, Manchester, UK), PDQuest system (Bio-Rad laboratories, Hercules, CA), Mascot Distiller and Mascot Database plasmid pcDNA3.1-RKIP-3xFLAG was transfected into SGC7901 cells

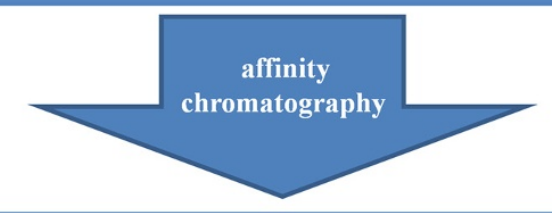

RKIP fusion proteins after purified

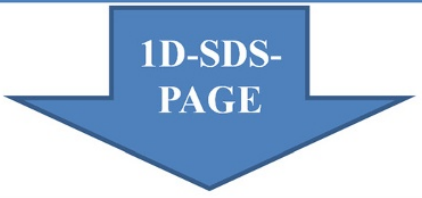

14 clear protein channels were separated

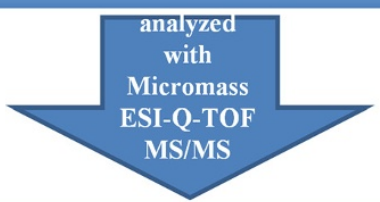

72 RKIP-interacted proteins were identified
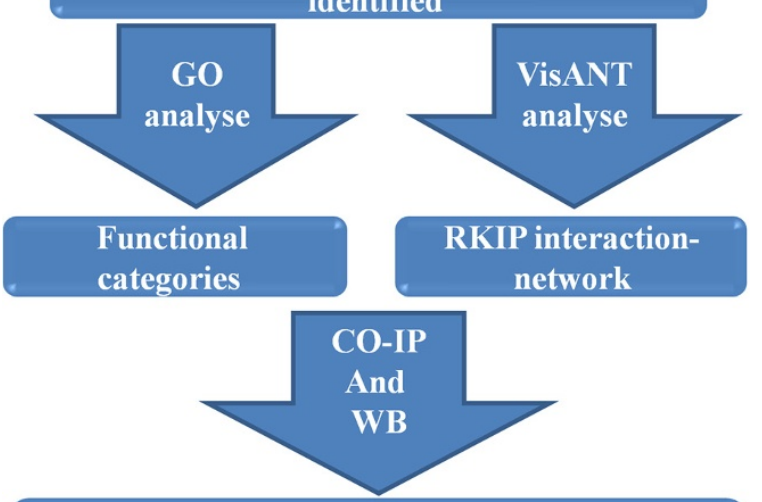

discover the interaction of RKIP with HSP90, 14-3-3, and keratin

Figure 1 Overall scheme of the experiments used to identify and analyze the proteins that interact with RKIP in the GC biology.

Search engine, and Statistical Package For Social Science (SPSS for windows, Version 17.0, Chicago, IL, USA) were used.

\section{Cell lines and plasmid}

Human gastric carcinoma cells (SGC7901) were purchased from the Laboratory for Cancer Research (Central South University, China). SGC7901 cells were cultured with RPMI1640 medium containing 10\% fetal calf serum (Gibco BRL, Grand Island, NY). The pCDNA3.1-RKIP-3xFLAG plasmid, pcDNA3.1-3xFLAG plasmid, and pcDNA3.1- 
RKIP plasmid were purchased from Yingrun Biotechnology Co., Ltd. A total of four experimental groups were set up: SGC7901 cells tranfected with pcDNA3.1-RKIP3xFLAG plasmid (RKIP-3xFLAG group), SGC7901 cells tranfected with pcDNA3.1-3xFLAG plasmid (3xFLAG group), SGC7901 cells tranfected with pcDNA3.1-RKIP plasmid (RKIP group), and SGC7901 cells (Blank group).

\section{Transfection}

SGC7901 cells were recovered, cultured for logarithmic cell growth, then before transfection SGC7901 cells were plated into $15-\mathrm{cm}^{2}$ petri dishes. The cells were used for transfection when the cell reached $90 \%$ confluency and were assigned to either the RKIP-3xFLAG group (fusion carrier group), the 3XFLAG group (blank carrier group), RKIP group (which was used to validate whether 3xFLAG affects the expression of RKIP), or the blank group. Transfection was conducted according to the LipofectamineTM2000 instructions for liposome transfection.

\section{Western blot analysis of RKIP and fusion proteins}

The expressions of RKIP proteins and RKIP-3xFLAG fusion proteins were detected by Western blot analysis after transfection. The procedure was performed as follows: the cells were collected from the flasks, washed three times with cold $\mathrm{PBS}$, and lysed $\left(4^{\circ} \mathrm{C}, 30 \mathrm{~min}\right)$ in a lysis buffer. The protein concentration was determined with a protein assay kit (Bio-Rad laboratories). Protein extracts (about $20 \mathrm{mg}$ ) were subjected to SDS-PAGE with a $10 \%$ acrylamide gel. The gel-separated proteins were transferred to PVDF membranes (Millipore Corporation, Bedford, MA), incubated with primary antibodies, including anti-RKIP, anti-Flag, and anti- $\beta$-actin antibodies (Santa Cruz biotechnology, Santa Cruz, CA), and probed with secondary antibodies. The PVDF membranes with protein-antibody complexes were washed tree times with TBST buffer. The proteins on the PVDF membranes were visualized with the enhanced chemiluminescence (ECL) detection system. Western blot analysis was repeated at least three times.

\section{Purification of RKIP fusion proteins}

The proteins from the RKIP-3xFLAG group, 3xFLAG group, and blank group were purified according to the FLAG M2 magnetic beads manual procedures of protein purification (each experimental step was conducted at $2-8^{\circ} \mathrm{C}$ ), respectively. Briefly, an adequate amount of affinity gel in a clean centrifuge tube was centrifuged $(5,878 \mathrm{xg}$, $30 \mathrm{sec}$ ) and was allowed to precipitate (approximately $2 \mathrm{~min}$ ). The supernatant was discarded and the precipitate was washed twice with TBS solution that was equivalent to 20 -fold volumes of the magnetic bead solution. The supernatant was discarded, and the pellet was washed with $0.1 \mathrm{M}$ glycine ( $\mathrm{pH}$ 3.5) $\mathrm{HCl}$ (20 min). The protein samples and affinity gel were mixed and incubated (overnight, $4^{\circ} \mathrm{C}$ ). The incubated mixture was centrifuged $\left(4^{\circ} \mathrm{C}, 5,878 \mathrm{xg}\right.$, $30 \mathrm{sec}$ ), and the supernatant was carefully removed. The pellet was treated with a pre-chilled solution. The proteins from each group were denatured in a boiling water bath (3 min), centrifuged $(2,296 \mathrm{xg}, 30 \mathrm{sec})$, and stored at low temperature $\left(-80^{\circ} \mathrm{C}\right)$ for further analyses.

\section{MS/MS-identification of proteins}

After 1D SDS-PAGE separation of the purified proteins from three groups (RKIP-3xFLAG, 3xFLAG, and Blank), respectively,the proteins that were contained in the gel bands were digested with trypsin, and the tryptic peptide mixture was analyzed with Micromass ESI-Q-TOF MS/MS. The tryptic peptide samples were loaded onto a pre-column $(320 \mu \mathrm{m} \times 50 \mathrm{~mm}, 5 \mu \mathrm{m} \mathrm{C} 18$ silica beads; Waters) to be concentrated and quickly desalted (30 l/min flow-rate) through a Waters CapLC autosampler. The concentrated and desalted tryptic peptides were online eluted to the reversed-phase column $(75 \mu \mathrm{m} \times 150 \mathrm{~mm}, 5 \mathrm{~mm}$, $100 \AA ̊$, LC Packing) at a flow-rate of $200 \mathrm{nl} / \mathrm{min}$. MS/MS spectra were acquired in a data-dependent mode in which up to four precursor ions above an intensity threshold of seven counts/second (cps) from each survey "scan" were selected for MS/MS analysis. The nanospray parameters were the following: a $3,000 \mathrm{~V}$ capillary voltage, a $45 \mathrm{~V}$ cone voltage, an $80^{\circ} \mathrm{C}$ source temperature, and a 15 -psi collision gas back pressure. The MS/MS data were used to search the identified proteins against the protein database with the Mascot search engine. The search parameters used were the following: homo sapiens as the current species, a mass tolerance of +0.5 Da, an MS/MS tolerance of $+0.3 \mathrm{Da}$, up to 1 missed cleavage site, fixed carboxymethyl (cysteine) modification, variable oxidation (methylation) modification, the Micromass PKL format, and the ESI Q-TOF instrument. The proteins identified from the blank-carrier control group and from the blank control group were regarded as non-specific proteins, and were removed from the protein list identified from the pcDNA3.1-RKIP-3xFLAG test group to rule out the nonspecifically binding proteins of RKIP.

\section{Co-immunoprecipitation}

A volume $(1 \mathrm{ml})$ of extraction buffer that contained $1.5 \mathrm{mg}$ of protein from cells was mixed with $5 \mu \mathrm{l}$ of nonimmune rabbit serum and $50 \mu \mathrm{l}$ of protein G-sepharose $4 \mathrm{~B}$ beads was oscillated $\left(40^{\circ} \mathrm{C}, 2 \mathrm{~h}\right)$ and centrifuged $(2,296 \mathrm{xg}, 3 \mathrm{~min})$ to eliminate the nonspecific binding of proteins. After centrifugation, the supernatant was retained and mixed with $20 \mu \mathrm{g}$ of RKIP antibodies and $50 \mu \mathrm{L}$ of protein G-sepharose $4 \mathrm{~B}$ beads $\left(40^{\circ} \mathrm{C}\right.$, oscillation, $\left.3 \mathrm{~h}\right)$. The mixture was centrifuged (2,296 x g, $3 \mathrm{~min})$. The beads were retained and washed three times with TBST buffer. Non- 
immune IgY antibodies, instead of RKIP antibodies, were used as controls.

\section{Construction of the RKIP-interaction protein network diagrams}

VisANT 3.8.6 software (http://visant.bu.edu/) was used to analyze and construct the RKIP-interaction protein network diagrams. VisANT is an interactive software platform that is to visualize, mine, analyze, and model biological networks. When VisANT was used in this study, homo sapiens was selected for the current species parameter, and the Uniprot IDs of RKIP and of the 72 identified proteins were entered into the search box. Three databases, including Michigan Molecular Interactions (MiMI), functional linage network, and Predictome, were chosen to acquire the interaction network diagrams. The MiMI tool was provided by the National Institute of Health's National Center for Integrative Biomedical Informatics. The MiMI tool provides access to the knowledge and data that have been merged and integrated from numerous protein-interaction databases, and it augments the information from many other biological sources. The Predictome database is based on the implementation of published computational methods and publicly available data and can precisely predict the connections between proteins; the associations are created using a variety of techniques, both experimental (yeast two-hybrid, immunocoprecipitation, correlated expression) and computational (gene fusion, chromosomal proximity, gene co-evolution).

For the constructed protein network diagrams, each protein was located on a different level based on the interaction between that protein and RKIP. The 1st level neighbors were the directly interacting proteins, the 2nd level neighbors are the secondary interacting proteins, and the 3rd level neighbors were the tertiary interacting proteins. The 1st and 2nd level neighbors in the RKIP-interaction protein networks were considered to be the closely interacting proteins of RKIP because the interactions of RKIP with the 1st and 2nd level neighbors were much closer than those with the other level neighbors.

\section{Validation of RKIP-related proteins}

Western blot analysis and co-immunoprecipitation were used to validate the interactions of HSP90, 14-3-3e, and Keratin 8 with RKIP. The total protein from SGC7901 cells was precipitated in an appropriate lysis buffer containing RKIP antibody. The immunoprecipitated proteins were further analyzed by SDS-PAGE. Western blot analysis was used to detect HSP90, 14-3-3e, and keratin 8 with their corresponding antibodies in order to study the target proteins' interactions with RKIP. Non-immune IgY antibodies replaced the RKIP antibodies as negative controls $(3 \times)$.

\section{Statistical analysis}

All experiment data were expressed as mean $\pm \mathrm{SE}$ and analyzed with Student's $t$-test with a statistical significance level of $\mathrm{p}<0.05$.

\section{Results}

\section{Expression of RKIP protein in transfected cells}

The expression level of RKIP protein in transfected cells was determined by Western blot analysis. The intensity of the Western blot images was analyzed with IPP 6.0 software and represented the relative amount of protein expression. The Western blot analysis shows that the RKIP expression levels of the RKIP-3xFLAG group and of the RKIP group were significantly higher than those of the 3xFLAG group $(\mathrm{p}<0.05$; Figure 2$)$.

\section{Purification of RKIP fusion proteins}

After the affinity-magnetic bead purification, with antiflag M2 magnetic beads, of the total protein from the cells, most of the protein sample was pre-separated by 1D-SDS-PAGE using a 10\% acrylamide gel. The experiment was repeated three times with the same test conditions and parameter settings, and then the gel images were obtained with clear backgrounds, high resolution, and good reproducibility. A total of 14 RKIP interacting protein bands were identified (Figure 3A).

Western blot analysis was used to test the remaining protein samples. The results demonstrated that no cross-

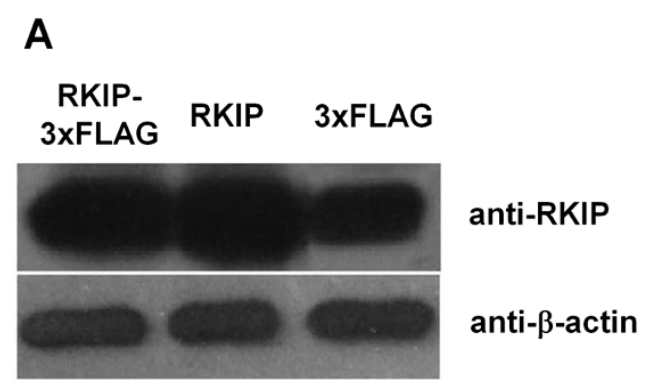

B

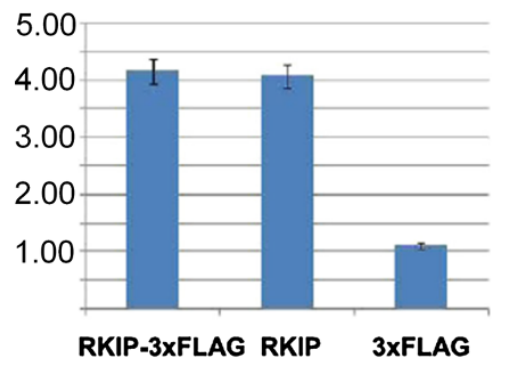

Figure 2 The expression levels of RKIP in RKIP-3xFLAG, RKIP, and 3xFLAG groups. A. Western blot image. B. The intensity of the bands in the Western blot image $(p<0.05)$. The 3xFLAG did not affect the expression of RKIP. 


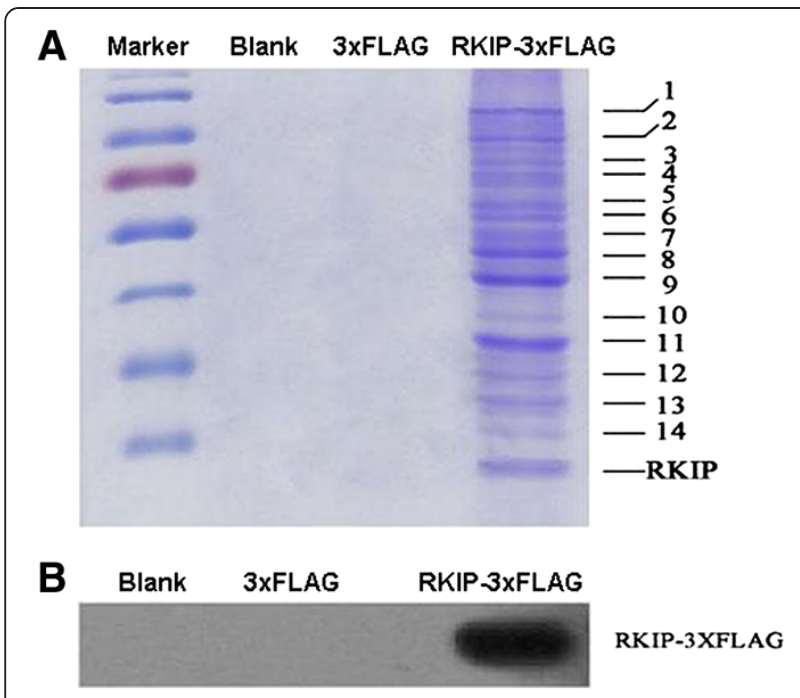

Figure 3 Separation of RKIP-interacting proteins with anti-flag M2 magnetic beads and 1D SDS-PAGE. A. After the affinity

magnetic bead based purification, with anti-flag M2 magnetic beads, of total protein from the cells, the protein sample was pre-separated by 1D-SDS-PAGE using a 10\% acrylamide gel. The clear channel proteins $(n=14)$ were separated in the experimental group. B. Western blot analysis to test RKIP-3xFLAG expression in different groups of affinity purified cells. After the affinity magnetic bead based purification, with anti-flag M2 magnetic beads, of total protein from the cells, RKIP-3xFLAG expression was detected in only the RKIP-3xFLAG group, whereas no RKIP-3xFLAG expression was detected in the 3xFLAG and blank groups.

contamination between the experimental and control groups occurred; three reproducible tests confirmed the reliability (Figure $3 \mathrm{~B}$ ).

\section{Identification of RKIP-related proteins}

The RKIP-related proteins were separated with 1D-SDSPAGE and visualized with Coomassie brilliant blue R250. The proteins in the gel-bands were subjected to in-gel trypsin digestion. The tryptic peptides were analyzed with ESI-Q-TOF MS/MS. The obtained MS/MS data were used to identify the proteins with Mascot software to search the Swiss-Prot or the NCBInr database; this experiment was repeated three times. The proteins that only appeared in the RKIP-3xFLAG group were chosen to effectively rule out the non-specific proteins. However, no proteins were identified by MS/MS in the 3xFLAG and blank groups, which is consistent with the results of gel-image without any protein band in the Figure 3. This confirmed that the identified proteins from the pcDNA3.1-RKIP-3xFLAG group were the RKIPinteracting proteins. A total of 72 proteins were MS/ MS-identified (Table 1; Additional file 1: Table S1). The identified proteins belong to different functional categories (Figure 4; Table 1), including metabolic enzymes $(\mathrm{n}=13 ; 18 \%)$, molecular chaperones $(\mathrm{n}=8 ; 11 \%)$, biological oxidation-related proteins $(\mathrm{n}=2 ; 3 \%)$, signal transductionrelated proteins $(\mathrm{n}=8 ; 11 \%)$, cytoskeleton-related proteins $(\mathrm{n}=16 ; 22 \%)$, protease-related proteins $(\mathrm{n}=18$; $25 \%)$, and others $(n=7 ; 10 \%)$. The same proteins (14-3-3, keratin, filamin, tubulin, GSTP1, HSP90, DHX9, actin, and vimentin) were consistently identified in three repeated experiments.

\section{RKIP-interaction protein network diagrams and validation of the RKIP-protein complex}

VisANT software with three functional models (MiMI, functional linkage network, and Predictome) was used to search for interactions between RKIP and the 72 identified proteins, to construct the RKIP interaction network diagram, and to define the levels of interaction between the identified proteins and RKIP (Figure 5).

In the protein network diagram that was derived from the database retrieval with MiMI, among the 72 RKIPrelated proteins, 16 proteins were classified as the 1st level neighbors of RKIP, 19 proteins were classified as the 2nd level neighbors of RKIP, 29 proteins were classified as the 3rd level neighbors of RKIP, and 8 proteins were found to not interact with RKIP (Figure 5A, Table 2).

In the protein network diagram that was derived from the database retrieval with the functional linage network, among the 72 RKIP-related proteins, 41 proteins were classified as the 1st level neighbors of RKIP, 21 proteins were classified as the 2nd level neighbors of RKIP, and 10 proteins were classified as the 3rd level neighbors of RKIP (Figure 5B, Table 2).

In the protein network diagram that was derived from the database retrieval with Predictome, among the 72 RKIP-related proteins, 43 proteins were classified as the 1st level neighbors of RKIP, 16 proteins were classified as the 2nd level neighbors of RKIP, 9 proteins were classified as the 3rd level neighbors of RKIP, and 4 proteins were found to not interact with RKIP (Figure 5C, Table 2).

Of the 72 RKIP-related proteins, only 35 proteins closely interacted with RKIP, as determined from the MiMI analysis. However, all 72 proteins had functional relationships with RKIP with the functional linage network and Predictome database analyses, and 69 proteins were predicted to closely interact with RKIP. In all three database analyses, 35 proteins were consistently found to be closely related to RKIP, including HSP90, 14-33e, Keratin 8, IQGAP1, MYH9, CLH1, PLEC1, and EF2 (Table 2).

In our previous study, HSP90, 14-3-3e, and keratin 8 were discovered to be significantly changed in the GC tissues compared with in the normal gastric mucosa tissues [3]. MiMI, functional linage network, and Predictome were three independent software and databases. Through the MiMI analysis, these proteins were classified as 2nd level neighbors of RKIP; through the functional 
Table 1 RKIP-related proteins identified with ESI-Q-TOF MS/MS

\begin{tabular}{|c|c|c|c|c|c|}
\hline UniProt ID & Protein name & $\begin{array}{l}\text { Protein mass } \\
(\mathrm{Da})\end{array}$ & Score & $\begin{array}{l}\text { Matching } \\
\text { peptides }\end{array}$ & Protein function \\
\hline \multicolumn{6}{|c|}{ 1. Metabolic enzymes } \\
\hline P53618 & Coatomer subunit beta & 108,241 & 89 & 3 & Mediate biosynthetic protein transport \\
\hline P14618 & Pyruvate kinase isozymes $M 1 / M 2$, isoform $M 2$ & 58,470 & 604 & 40 & Glycolytic enzyme \\
\hline P00966 & Argininosuccinate synthase & 46,791 & 142 & 6 & ATP binding \\
\hline P00558 & Phosphoglycerate kinase 1 & 44,992 & 102 & 3 & Glycolytic enzyme \\
\hline P08195 & $\begin{array}{l}4 \mathrm{~F} 2 \text { cell-surface antigen heavy chain, } \\
\text { isoform } 2\end{array}$ & 68,180 & 56 & 2 & Function of light chain amino-acid transporters \\
\hline P06733 & Alpha-enolase & 47,481 & 517 & 25 & Multifunctional enzyme \\
\hline P04406 & Glyceraldehyde-3-phosphate dehydrogenase & 36,201 & 769 & 80 & $\begin{array}{l}\text { Glyceraldehyde-3-phosphate dehydrogenase } \\
\text { and nitrosylase activities }\end{array}$ \\
\hline P07195 & L-lactate dehydrogenase B chain & 36,900 & 74 & 5 & L-lactate dehydrogenase activity \\
\hline P00338 & L-lactate dehydrogenase A chain, isoform 1 & 36,950 & 43 & 4 & L-lactate dehydrogenase activity \\
\hline P40926 & Malate dehydrogenase, mitochondrial & 35,937 & 49 & 3 & L-malate dehydrogenase activity \\
\hline P46940 & Ras GTPase-activating-like protein IQGAPI & 189,761 & 55 & 3 & Promote neurite outgrowth \\
\hline P68104 & Elongation factor 1-alpha 1 & 50,451 & 190 & 11 & Protein biosynthesis \\
\hline P02786 & Transferrin receptor protein 1 & 85,274 & 74 & 3 & Molecular transducer activity \\
\hline \multicolumn{6}{|c|}{ II. Molecular chaperone } \\
\hline P14625 & Endoplasmin & 92,696 & 192 & 18 & Molecular chaperone ATPase activity \\
\hline P07900 & Heat shock protein HSP 90-alpha, isoform 2 & 85,006 & 280 & 24 & Stress related, chaperone \\
\hline P08238 & Heat shock protein HSP 90-beta & 83,554 & 276 & 25 & Stress related, chaperone \\
\hline P11142 & $\begin{array}{l}\text { Heat shock cognate } 71 \text { kDa protein, } \\
\text { isoform } 1\end{array}$ & 71,082 & 398 & 16 & Stress related, chaperone \\
\hline P38646 & Stress-70 protein, mitochondrial & 73,920 & 253 & 7 & Related with cellular proliferation and aging \\
\hline P10809 & $60 \mathrm{kDa}$ heat shock protein, mitochondrial & 61,187 & 723 & 22 & Stress related, chaperone \\
\hline P53992 & Protein transport protein Sec $24 C$ & 119,789 & 61 & 5 & Component of the COPII coat \\
\hline P50454 & Serpin $\mathrm{H} 1$ & 46,525 & 133 & 3 & $\begin{array}{l}\text { Chaperone in the biosynthetic pathway of } \\
\text { collagen }\end{array}$ \\
\hline \multicolumn{6}{|c|}{ III. Biological oxidation-related proteins } \\
\hline O00299 & Chloride intracellular channel protein 1 & 27,248 & 78 & 3 & $\begin{array}{l}\text { Voltage-gated chloride channel activity, } \\
\text { redox-regulated }\end{array}$ \\
\hline Q06830 & Peroxiredoxin-1 & 22,324 & 51 & 7 & Redox regulation \\
\hline \multicolumn{6}{|c|}{ IV. Signal transduction } \\
\hline O43390 & Heterogeneous nuclear ribonucleoprotein R, isoform 1 & 71,184 & 63 & 2 & mRNA processing, ribonucleoprotein \\
\hline P52597 & Heterogeneous nuclear ribonucleoprotein F & 45,985 & 110 & 2 & mRNA processing, ribonucleoprotein \\
\hline P04083 & Annexin A1 & 38,918 & 454 & 24 & Signal transduction, calcium ion binding \\
\hline P12429 & Annexin A3 & 36,524 & 53 & 4 & Signal transduction, calcium ion binding \\
\hline P08758 & Annexin A5 & 35,971 & 50 & 10 & Signal transduction, calcium ion binding \\
\hline P62258 & 14-3-3 protein epsilon & 29,326 & 136 & 6 & $\begin{array}{l}\text { Anti-apoptosis, signal transduction, } \\
\text { transcription factor binding }\end{array}$ \\
\hline P23396 & 40 S ribosomal protein $\mathrm{S} 3$ & 26,842 & 122 & 9 & NF-KappaB binding \\
\hline Q99623 & Prohibitin-2 & 33,276 & 38 & 5 & Mediate transcriptional repression \\
\hline \multicolumn{6}{|c|}{ V. Cytoskeleton-related proteins } \\
\hline O75369 & Filamin-B, isoform 1 & 280,157 & 91 & 1 & $\begin{array}{l}\text { Connects cell membrane constituents to } \\
\text { the actin cytoskeleton }\end{array}$ \\
\hline P21333 & Filamin-A, isoform 2 & 283,301 & 91 & 3 & Actin binding \\
\hline P18206 & Vinculin, isoform 1 & 124,292 & 668 & 30 & Actin filament-binding protein \\
\hline
\end{tabular}


Table 1 RKIP-related proteins identified with ESI-Q-TOF MS/MS (Continued)

\begin{tabular}{|c|c|c|c|c|c|}
\hline P04264 & Keratin, type II cytoskeletal 1 & 66,170 & 89 & 4 & Cytoskeleton of Intermediate filaments \\
\hline P05787 & Keratin, type II cytoskeletal 8 & 53,671 & 156 & 11 & Cytoskeleton of Intermediate filaments \\
\hline Q04695 & Keratin, type I cytoskeletal 17 & 48,361 & 221 & 10 & Cytoskeleton of Intermediate filaments \\
\hline P05783 & Keratin, type I cytoskeletal 18 & 48,029 & 547 & 35 & Cytoskeleton of Intermediate filaments \\
\hline Q15149 & Plectin-1, isoform 1 & 533,462 & 73 & 11 & Actin binding \\
\hline P35579 & Myosin-9, isoform 1 & 227,646 & 62 & 10 & Play a role in cytokinesis, secretion \\
\hline P68371 & Tubulin beta-2C chain & 50,255 & 245 & 19 & The major constituent of microtubules \\
\hline P07437 & Tubulin beta chain & 50,095 & 309 & 25 & The major constituent of microtubules \\
\hline P60709 & Actin, cytoplasmic 1 & 42,058 & 617 & 36 & Involved in various types of cell motility \\
\hline P52907 & F-actin-capping protein subunit alpha-1 & 33,073 & 61 & 3 & Actin binding \\
\hline P04075 & Fructose-bisphosphate aldolase A & 39,851 & 141 & 7 & Actin binding \\
\hline P08670 & Vimentin & 53,619 & 574 & 17 & $\begin{array}{l}\text { Cell motility, structural constituent of } \\
\text { cytoskeleton }\end{array}$ \\
\hline Q9NYL9 & Tropomodulin-3 & 39,741 & 85 & 9 & Actin binding \\
\hline \multicolumn{6}{|c|}{ VI. Protease-related proteins } \\
\hline P53396 & ATP-citrate synthase & 121,674 & 225 & 7 & Enzyme regulator activity \\
\hline P55072 & Transitional endoplasmic reticulum ATPase & 89,950 & 42 & 3 & $\begin{array}{l}\text { Necessary for the formation of transitional } \\
\text { endoplasmic reticulum }\end{array}$ \\
\hline Q08J23 & tRNA (cytosine-5-)-methyl transferase NSUN2 & 87,214 & 78 & 2 & RNA methyltransferase \\
\hline P06576 & ATP synthase subunit alpha, mitochondrial & 59,828 & 158 & 9 & Mitochondrial membrane ATP synthase \\
\hline P60842 & Eukaryotic initiation factor 4A-I & 46,357 & 169 & 7 & ATP-dependent RNA helicase \\
\hline P55786 & Puromycin-sensitive aminopeptidase & 103,895 & 117 & 3 & $\begin{array}{l}\text { Involved in proteolytic events essential for } \\
\text { cell growth and viability }\end{array}$ \\
\hline P50395 & Rab GDP dissociation inhibitor beta & 51,095 & 78 & 3 & Rad GDP-dissociation inhibitor activity \\
\hline P42330 & Aldo-keto reductase family 1 member C3 & 37,229 & 35 & 2 & Aldo-keto reductase activity \\
\hline P63244 & $\begin{array}{l}\text { Guanine nucleotide-binding protein } \\
\text { subunit beta-2-like } 1\end{array}$ & 35,511 & 112 & 3 & Up-regulation of the activity of kinases \\
\hline P61289 & $\begin{array}{l}\text { Proteasome activator complex subunit 3, } \\
\text { isoform } 1\end{array}$ & 29,602 & 77 & 2 & Endopeptidase activator activity \\
\hline P09211 & Glutathione S-transferase P & 23,569 & 56 & 30 & Glutathione transferase activity \\
\hline P13639 & Elongation factor 2 & 96,246 & 240 & 9 & $\begin{array}{l}\text { Catalyzes the GTP-dependent ribosomal } \\
\text { translocation }\end{array}$ \\
\hline Q15029 & $\begin{array}{l}116 \mathrm{kDa} \text { U5 small nuclear ribonucleoprotein } \\
\text { component }\end{array}$ & 110,336 & 130 & 6 & Component of the U5 snRNP complex \\
\hline P10696 & Alkaline phosphatase, placental-like & 57,626 & 140 & 8 & Alkaline phosphatase activity \\
\hline Q99714 & $\begin{array}{l}\text { 3-hydroxyacyl-CoA dehydrogenase type-2, } \\
\text { isoform } 1\end{array}$ & 27,134 & 108 & 3 & Mitochondrial tRNA maturation \\
\hline Q08211 & ATP-dependent RNA helicase A & 142,181 & 264 & 12 & Transcriptional activator \\
\hline P41252 & Isoleucyl-tRNA synthetase, cytoplasmic & 145,718 & 94 & 9 & Isoleucine-tRNA ligase activity \\
\hline P26640 & Valyl-tRNA synthetase & 141,642 & 78 & 4 & ATP binding \\
\hline \multicolumn{6}{|c|}{ VII. Others } \\
\hline Q13263 & $\begin{array}{l}\text { Transcription intermediary factor 1-beta, } \\
\text { isoform } 1\end{array}$ & 90,261 & 59 & 3 & $\begin{array}{l}\text { Nuclear corepressor for KRAB } \\
\text { domain-containing zinc finger proteins }\end{array}$ \\
\hline Q14974 & Importin subunit beta-1 & 98,420 & 84 & 2 & Protein domain specific binding \\
\hline P26641 & Elongation factor 1-gamma & 50,429 & 65 & 2 & Unknown \\
\hline P21796 & $\begin{array}{l}\text { Voltage-dependent anion-selective channel } \\
\text { protein } 1\end{array}$ & 30,868 & 78 & 3 & Voltage-gated anion channel activity \\
\hline P61026 & Ras-related protein Rab-1A, isoform 1 & 22,755 & 45 & 1 & $\begin{array}{l}\text { Involved in vesicular trafficking and } \\
\text { neurotransmitter release. }\end{array}$ \\
\hline
\end{tabular}


Table 1 RKIP-related proteins identified with ESI-Q-TOF MS/MS (Continued)

\begin{tabular}{llllll}
\hline Q00610 & Clathrin heavy chain 1, isoform 1 & 193,620 & 36 & 3 & The polyhedral coat of coated pits and vesicles \\
Q14683 & $\begin{array}{l}\text { Structural maintenance of chromosomes } \\
\text { protein 1A }\end{array}$ & 143,771 & 221 & 6 & Involved in chromosome cohesion \\
\hline
\end{tabular}

linage network analysis, they were found to be directly functionally related to RKIP; and through the Predictome analysis, they were found to directly interact with RKIP. Those three proteins were further verified by Western blot analysis in combination with co-immunoprecipitation; the results confirmed the proteins' interactions with RKIP. The results show that the protein expressions of the MS/MScharacterized HSP90, 14-3-3e, and keratin 8 (Additional file 2: Table S2) were detected in the RKIP immune complex (Figure 6) and they were not detected when the RKIP antibody was replaced by IgY antibody.

\section{Discussion}

The RKIP that was found to be down-regulated or absent in GC in our previous study [3], which is associated with the occurrence, differentiation, invasion, and metastasis of GC. Recent studies further found that RKIP can prevent the phosphorylation and activation of MEK that is mediated by the RAF-1 and MAPK signaling pathways [9]. RKIP can also participate in the regulation and control of the $\mathrm{G}$ protein coupling receptor signaling pathway and the NF-kB signaling pathway $[16,27]$. These signaling pathways play important roles in cell growth, proliferation, differentiation, and tumorigenesis processes, which strongly suggests that abnormal expression of RKIP is involved in tumorigenesis. Our previous study also revealed that the abnormal expression of RKIP plays an important role in the growth and differentiation process of GC.

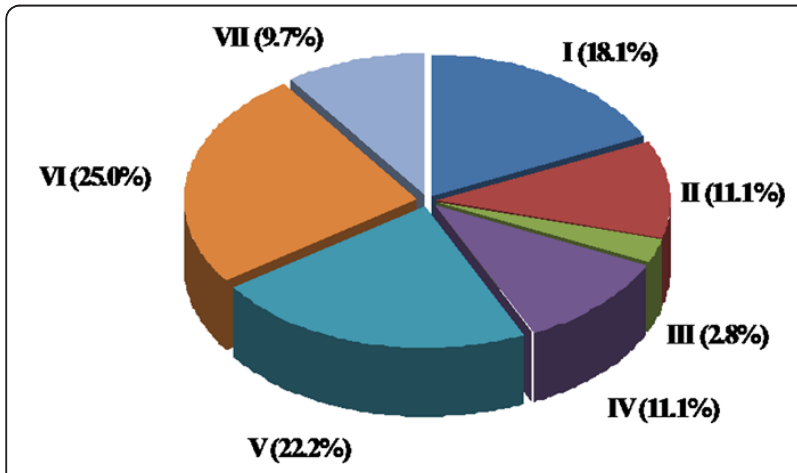

Figure 4 Functional categories of RKIP-interacting proteins ( $\mathbf{n}=\mathbf{7 2}$ ). I. Metabolic enzymes $(n=13 ; 18 \%)$; II. Molecular chaperones $(n=8 ; 11 \%)$; III. Biological oxidation-related proteins $(n=2 ; 3 \%)$; IV. Signal transduction-related proteins $(n=8 ; 11 \%) ; V$. Cytoskeleton-related proteins ( $n=16 ; 22 \%)$; VI. Protease-related proteins ( $n=18 ; 25 \%)$; and VII. Others $(n=7 ; 10 \%)$.
Among numerous signaling pathways, the MAPK pathway plays a crucial role in inflammatory signal transduction, apoptosis, and tumor cell proliferation, and it controls a variety of internal metabolic process. Extracellular signal-regulated kinase (ERK) is a member of the MAPK family. Its RAS/RAF/MEK/ERK signal transmission pathway is the core of the signal network, which is involved in the regulation of cell growth, development, and division $[9,17,28]$.

RKIP can prevent the phosphorylation and activation of MEK that is mediated by RAF-1; thus RKIP can also influence the MAPK signaling pathway by combining with its interacting proteins. Therefore, we aim to study the RKIPinteracting proteins in GC and the action mechanism of the RAF/MEK/ERK signaling pathways which are influenced by RKIP in this paper.

Proteomics in combination with fusion protein expression is the first approach to characterize RKIP-interacting proteins. A total of 72 RKIP-related proteins were identified in the human gastric carcinoma cell line SGC7901. The identified proteins belong to different functional categories, including those of metabolic enzymes, molecular chaperones, biological oxidation-related proteins, signal transduction-related proteins, cytoskeleton-related proteins, protease-related proteins, and others. Among those 72 proteins, only 35 proteins were found through the MiMI analysis to have existing interactions with RKIP; however, through the functional linage network and the Predictome database analyses, each of the 72 proteins was found to be functionally related to RKIP, and 69 of the proteins were found to closely interact with RKIP.

Studies have demonstrated that some of the 72 related proteins, including MYH9, IQGAP1, annexin A1, vimentin, and GSTP1, might play an important role in the occurrence, differentiation, invasion, and metastasis of GC. The protein MYH9 functions in cytokinesis, cell motility, and the maintenance of cell shape. Many studies suggest that MYH9/NMHC-IIA plays a key role in tumor cell invasive behavior; and a recent study shows that the inhibition of MYH9/NMHC-IIA expression can inhibit the metastasis of GC cells [29]. IQGAP1 was discovered to be upregulated in GC, and its absence corresponds to a good clinical prognosis [30]. The loss of annexin A1 expression has been significantly associated with advanced stage lymph node metastasis, an advanced disease stage, and poor histological differentiation. The ANXA1 expression decreased significantly as GC progressed and metastasized; this result suggests the importance of ANXA1 as a negative biomarker 


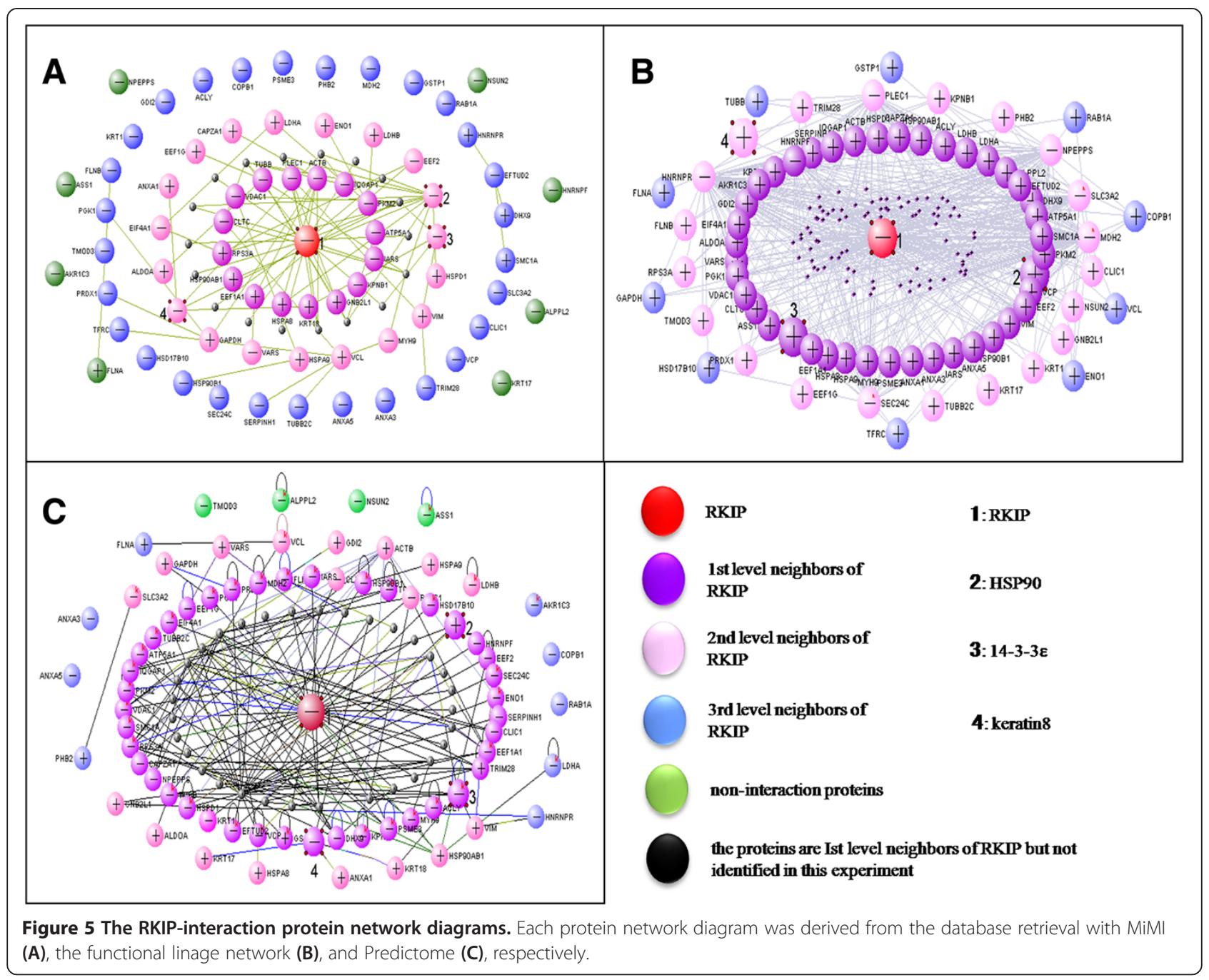

for GC development and progression [31]. Studies have demonstrated that the expression of vimentin was significantly upregulated in GC tissue and that the elevated vimentin expression was strongly correlated with lymph node metastasis, lymphatic invasion, perineural invasion, and pathological staging [32]. A recent study found that GSTP1 mRNA and protein were present in drug resistant gastric cells (including SGC7901 cells) and that the downregulated expression of GSTP1 was related to somatic promoter hypermethylation and impaired ERK signaling in GC cell lines [33].

HSP90 and 14-3-3 were found to be significantly changed in the GC tissues compared with in the normal gastric mucosa tissues in our previous study [3]. In this study, HSP90 and 14-3-3 were identified as 2nd level neighbors of RKIP by the MiMI analysis (Figure 5A), as directly functionally related to RKIP by the functional linage network analysis (Figure 5B), and as likely to directly interact with RKIP by the Predictome analysis (Figure 5C). The interactions of RKIP with HSP90 and 14-3-3 proteins were verified by Western blot analysis in combination with co-immunoprecipitation (Figure 6). HSP90 and 143-3 proteins also play an important role in the RAF/ MEK/ERK signaling pathways $[34,35]$.

The heat shock protein 90 family is a group of highly conserved proteins and expressed in all eukaryotic cells. HSP90 is over-expressed in a variety of tumor cells. Liu et al. have confirmed that HSP90 is also over-expressed in SGC7901 GC cells [36]. In recent years, studies have confirmed that heat shock protein family members such as HSP90 may directly affect the anti-apoptotic mechanisms of cells, and that, because of HSP specific functions, HSP90 plays an important role in the regulation of the cell's anti-apoptotic reaction. In the RAF/MEK/ERK signaling pathways, the vital RAF-1 and MEK kinases have been found to be substrate proteins of HSP90. Experiments show that HSP90 is important for the regulation of RAF-1 protein activity, intracellular positioning, and stability. The use of HSP90 blockers to prevent the interaction of HSP90 and RAF-1 can lead to a quick 
Table 2 The levels of interaction between the identified proteins and RKIP that located in the RKIP-interaction protein network diagrams (Figure 5), analyzed with the VisANT 3.8.6 protein-network analysis package

\begin{tabular}{|c|c|c|c|c|}
\hline UniProt ID & Protein name & MiMI & Functional linage network & Predictome \\
\hline P46940 & Ras GTPase-activating-like protein IQGAP1 & $1^{\text {st }}$ & $1^{\text {st }}$ & $1^{\text {st }}$ \\
\hline P08238* & Heat shock protein HSP 90-beta & $2^{\text {nd }}$ & $1^{\text {st }}$ & $1^{\text {st }}$ \\
\hline Q14974 & Importin subunit beta-1 & $1^{\text {st }}$ & $2^{\text {nd }}$ & $1^{\text {st }}$ \\
\hline P11142 & Heat shock cognate $71 \mathrm{kDa}$ protein & $1^{\text {st }}$ & $1^{\text {st }}$ & $2^{\text {nd }}$ \\
\hline P14618 & Pyruvate kinase isozymes M1/M2 & $1^{\text {st }}$ & $1^{\text {st }}$ & $1^{\text {st }}$ \\
\hline P06576 & ATP synthase subunit alpha, mitochondrial & $1^{\text {st }}$ & $1^{\text {st }}$ & $1^{\text {st }}$ \\
\hline P07437 & Tubulin beta chain & $1^{\text {st }}$ & $3^{\text {rd }}$ & $1^{\text {st }}$ \\
\hline P68104 & Elongation factor 1-alpha 1 & $1^{\text {st }}$ & $1^{\text {st }}$ & $1^{\text {st }}$ \\
\hline P60709 & Actin, cytoplasmic 1 & $1^{\text {st }}$ & $1^{\text {st }}$ & $2^{\text {nd }}$ \\
\hline P05783 & Keratin, type I cytoskeletal 18 & $1^{\text {st }}$ & $2^{\text {nd }}$ & $2^{\text {nd }}$ \\
\hline Q15149 & Plectin & $1^{\text {st }}$ & $2^{\text {nd }}$ & $1^{\text {st }}$ \\
\hline P21796 & Voltage-dependent anion-selective channel protein 1 & $1^{\text {st }}$ & $1^{\text {st }}$ & $1^{\text {st }}$ \\
\hline P23396 & $40 S$ ribosomal protein $\mathrm{S} 3$ & $1^{\text {st }}$ & $2^{\text {nd }}$ & $1^{\text {st }}$ \\
\hline P63244 & Guanine nucleotide-binding protein subunit beta-2-like 1 & $1^{\text {st }}$ & $2^{\text {nd }}$ & $2^{\text {nd }}$ \\
\hline Q00610 & Clathrin heavy chain 1 & $1^{\text {st }}$ & $1^{\text {st }}$ & $1^{\text {st }}$ \\
\hline P41252 & Isoleucyl-tRNA synthetase, cytoplasmic & $1^{\text {st }}$ & $1^{\text {st }}$ & $1^{\text {st }}$ \\
\hline P60842 & Eukaryotic initiation factor $4 \mathrm{~A}-\mathrm{I}$ & $2^{\text {nd }}$ & $1^{\text {st }}$ & $1^{\text {st }}$ \\
\hline P04075 & Fructose-bisphosphate aldolase A & $2^{\text {nd }}$ & $1^{\text {st }}$ & $2^{\text {nd }}$ \\
\hline P52907 & F-actin-capping protein subunit alpha-1 & $2^{\text {nd }}$ & $1^{\text {st }}$ & $1^{\text {st }}$ \\
\hline P04406 & Glyceraldehyde-3-phosphate dehydrogenase & $2^{\text {nd }}$ & $3^{\text {rd }}$ & $2^{\text {nd }}$ \\
\hline P07195 & L-lactate dehydrogenase B chain & $2^{\text {nd }}$ & $1^{\text {st }}$ & $2^{\text {nd }}$ \\
\hline P04083 & Annexin A1 & $2^{\text {nd }}$ & $1^{\text {st }}$ & $2^{\text {nd }}$ \\
\hline P00338 & L-lactate dehydrogenase A chain & $2^{\text {nd }}$ & $1^{\text {st }}$ & $3^{\text {rd }}$ \\
\hline P62258* & 14-3-3 protein epsilon & $2^{\text {nd }}$ & $1^{\text {st }}$ & $1^{\text {st }}$ \\
\hline P26640 & Valyl-tRNA synthetase & $2^{\text {nd }}$ & $1^{\text {st }}$ & $2^{\text {nd }}$ \\
\hline P08670 & Vimentin & $2^{\text {nd }}$ & $1^{\text {st }}$ & $2^{\text {nd }}$ \\
\hline P35579 & Myosin-9 & $2^{\text {nd }}$ & $1^{\text {st }}$ & $1^{\text {st }}$ \\
\hline P18206 & Vinculin & $2^{\text {nd }}$ & $3^{\text {rd }}$ & $2^{\text {nd }}$ \\
\hline P13639 & Elongation factor 2 & $2^{\text {nd }}$ & $1^{\text {st }}$ & $1^{\text {st }}$ \\
\hline P07900 & Heat shock protein HSP 90-alpha & $2^{\text {nd }}$ & $1^{\text {st }}$ & $1^{\text {st }}$ \\
\hline P38646 & Stress-70 protein, mitochondrial & $2^{\text {nd }}$ & $1^{\text {st }}$ & $2^{\text {nd }}$ \\
\hline P10809 & $60 \mathrm{kDa}$ heat shock protein, mitochondrial & $2^{\text {nd }}$ & $1^{\text {st }}$ & $1^{\text {st }}$ \\
\hline P05787* & Keratin, type II cytoskeletal 8 & $2^{\text {nd }}$ & $2^{\text {nd }}$ & $1^{\text {st }}$ \\
\hline P06733 & Alpha-enolase & $2^{\text {nd }}$ & $3^{\text {rd }}$ & $1^{\text {st }}$ \\
\hline P26641 & Elongation factor 1-gamma & $2^{\text {nd }}$ & $2^{\text {nd }}$ & $1^{\text {st }}$ \\
\hline Q15029 & small nuclear ribonucleoprotein component & $3^{\text {rd }}$ & $1^{\text {st }}$ & $1^{\text {st }}$ \\
\hline P08195 & 4 F2 cell-surface antigen heavy chain & $3^{\text {rd }}$ & $2^{\text {nd }}$ & $2^{\text {nd }}$ \\
\hline P53396 & ATP-citrate synthase & $3^{\text {rd }}$ & $1^{\text {st }}$ & $1^{\text {st }}$ \\
\hline O75369 & Filamin-B & $3^{\text {rd }}$ & $2^{\text {nd }}$ & $1^{\text {st }}$ \\
\hline P53992 & Protein transport protein Sec24C & $3^{\text {rd }}$ & $2^{\text {nd }}$ & $1^{\text {st }}$ \\
\hline P53618 & Coatomer subunit beta & $3^{\text {rd }}$ & $3^{\text {rd }}$ & $3^{\text {rd }}$ \\
\hline P14625 & Endoplasmin & $3^{\text {rd }}$ & $1^{\text {st }}$ & $1^{\text {st }}$ \\
\hline Q13263 & Transcription intermediary factor 1-beta & $3^{\text {rd }}$ & $2^{\text {nd }}$ & $1^{\text {st }}$ \\
\hline
\end{tabular}


Table 2 The levels of interaction between the identified proteins and RKIP that located in the RKIP-interaction protein network diagrams (Figure 5), analyzed with the VisANT 3.8.6 protein-network analysis package (Continued)

\begin{tabular}{|c|c|c|c|c|}
\hline P02786 & Transferrin receptor protein 1 & $3^{\text {rd }}$ & $3^{\text {rd }}$ & $1^{\text {st }}$ \\
\hline P55072 & Transitional endoplasmic reticulum ATPase & $3^{\text {rd }}$ & $1^{\text {st }}$ & $1^{\text {st }}$ \\
\hline O43390 & Heterogeneous nuclear ribonucleoprotein $\mathrm{R}$ & $3^{\text {rd }}$ & $2^{\text {nd }}$ & $3^{\text {rd }}$ \\
\hline P68371 & Tubulin beta- $2 \mathrm{C}$ chain & $3^{\text {rd }}$ & $2^{\text {nd }}$ & $1^{\text {st }}$ \\
\hline P50454 & Serpin $\mathrm{H} 1$ & $3^{\text {rd }}$ & $1^{\text {st }}$ & $1^{\text {st }}$ \\
\hline P00558 & Phosphoglycerate kinase 1 & $3^{\text {rd }}$ & $1^{\text {st }}$ & $1^{\text {st }}$ \\
\hline P50395 & Rab GDP dissociation inhibitor beta & $3^{\text {rd }}$ & $1^{\text {st }}$ & $2^{\text {nd }}$ \\
\hline P40926 & Malate dehydrogenase, mitochondrial & $3^{\text {rd }}$ & $2^{\text {nd }}$ & $1^{\text {st }}$ \\
\hline Q99623 & Prohibitin-2 & $3^{\text {rd }}$ & $2^{\text {nd }}$ & $3^{\text {rd }}$ \\
\hline P12429 & Annexin A3 & $3^{\text {rd }}$ & $1^{\text {st }}$ & $3^{\text {rd }}$ \\
\hline P08758 & Annexin A5 & $3^{\text {rd }}$ & $1^{\text {st }}$ & $3^{\text {rd }}$ \\
\hline 000299 & Chloride intracellular channel protein 1 & $3^{\text {rd }}$ & $2^{\text {nd }}$ & $1^{\text {st }}$ \\
\hline P61289 & Proteasome activator complex subunit 3 & $3^{\text {rd }}$ & $1^{\text {st }}$ & $1^{\text {st }}$ \\
\hline P09211 & Glutathione S-transferase P & $3^{\text {rd }}$ & $3^{\text {rd }}$ & $1^{\text {st }}$ \\
\hline Q06830 & Peroxiredoxin-1 & $3^{\text {rd }}$ & $2^{\text {nd }}$ & $1^{\text {st }}$ \\
\hline P61026 & Ras-related protein Rab-10 & $3^{\text {rd }}$ & $3^{\text {rd }}$ & $3^{\text {rd }}$ \\
\hline Q99714 & 3-hydroxyacyl-CoA dehydrogenase type-2 & $3^{\text {rd }}$ & $3^{\text {rd }}$ & $1^{\text {st }}$ \\
\hline Q08211 & ATP-dependent RNA helicase A & $3^{\text {rd }}$ & $1^{\text {st }}$ & $1^{\text {st }}$ \\
\hline Q14683 & Structural maintenance of chromosomes protein $1 \mathrm{~A}$ & $3^{\text {rd }}$ & $1^{\text {st }}$ & $1^{\text {st }}$ \\
\hline P04264 & Keratin, type II cytoskeletal 1 & $3^{\text {rd }}$ & $1^{\text {st }}$ & $1^{\text {st }}$ \\
\hline Q9NYL9 & Tropomodulin-3 & $3^{\text {rd }}$ & $3^{\text {rd }}$ & N/A \\
\hline P21333 & Filamin-A & N/A & $3^{\text {rd }}$ & $3^{\text {rd }}$ \\
\hline P55786 & Puromycin-sensitive aminopeptidase & $\mathrm{N} / \mathrm{A}$ & $2^{\text {nd }}$ & $1^{\text {st }}$ \\
\hline P52597 & Heterogeneous nuclear ribonucleoprotein F & N/A & $1^{\text {st }}$ & $1^{\text {st }}$ \\
\hline Q04695 & Keratin, type I cytoskeletal 17 & N/A & $2^{\text {nd }}$ & $2^{\text {nd }}$ \\
\hline P42330 & Aldo-keto reductase family 1 member $\mathrm{C} 3$ & N/A & $1^{\text {st }}$ & $3^{\text {rd }}$ \\
\hline Q08J23 & tRNA (cytosine-5-)-methyltransferase NSUN2 & N/A & $2^{\text {nd }}$ & N/A \\
\hline P00966 & Argininosuccinate synthase & N/A & $1^{\text {st }}$ & N/A \\
\hline P10696 & Alkaline phosphatase, placental-like & N/A & $1^{\text {st }}$ & N/A \\
\hline
\end{tabular}

Note: $1^{\text {st }}$ means that the protein was located as the $1^{\text {st }}$ level neighbors of RKIP; $2^{\text {nd }}$ means that the protein was located as the $2^{\text {nd }}$ level neighbors of RKIP; $3^{\text {rd }}$ means that the protein was located as the $3^{\text {rd }}$ level neighbors of RKIP; and N/A means no interaction of RKIP with those proteins or the level of their interaction was $>$ the $3^{\text {rd }}$ level. *(bold font) means the validated proteins that interacted with RKIP.

decline of intracellular RAF-1 protein, block downstream MAPK activation, and induce apoptosis [34]. As the previous studies have proven, HSP90 protein plays an important role in the activation of the RAF/MEK/ ERK signaling pathways.

The 14-3-3 signaling proteins are a group of multifunctional eukaryotic proteins that are highly conserved and widely distributed. Some subtypes of 14-3-3 were found in GC cell lines with high expression [37]. The 14-3-3 protein, in partnership with cancer gene or proto-oncogene products, participates in cellular signal transduction, plays a role in RAF/RAS/MAPK signaling, directly affects the signal transmission related to phospholipid activity and $\mathrm{Ca}^{2+}$, and is involved in $\mathrm{T}$ cell activation and cell apoptosis [10,38]. Studies have confirmed that in the RAS/RAF/ERK/MEK signal transduction pathways, the combination of 14-3-3 and RAF multiple sites were the collaborative factor of RAF-1 and RAS. Additionally, RAF-1 was transferred to the cell membrane by 14-3-3, fixed in cell membrane by RAS, and then activated by 14-3-3. Therefore, 14-3-3 is the enzyme downstream of RAS, in the MAPK pathway, with which RAF-1 interacts $[39,40]$. Protein $14-3-3$ plays a major role in maintaining the stability of the RAS/RAF-1 complex and in forming membrane sites. The involvement of 14-3-3 protein in the regulation of the RAF/MEK/ERK signaling pathways has been reported [35]. Current research suggests that 14-3-3 $\sigma$, a member of the 14-3-3 


\section{IP: IgY control RKIP}

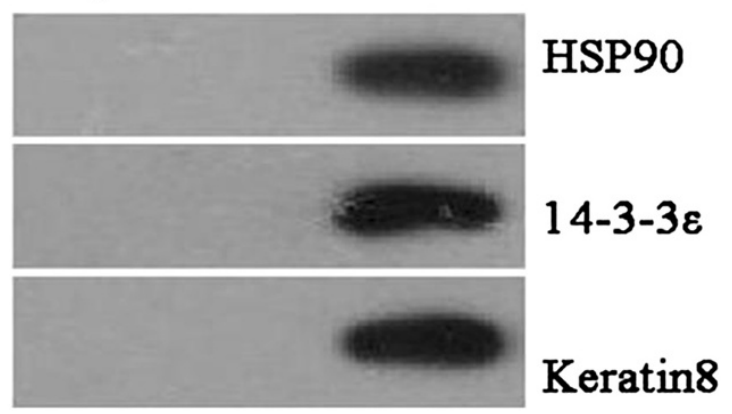

Figure 6 The validation of RKIP-interaction proteins with immunoprecipitation and Western blot analysis. The proteins were immunoprecipitated, with RKIP antibody, from the total protein extracts of SGC7901 cells and detected by Western blot analysis with antibodies against HSP90, 14-3-3E, and keratin 8. Non-immune IgY antibodies were used to replace RKIP antibodies as negative controls $(3 x)$

protein family, has tumor suppressor activity, while other members of the 14-3-3 protein family have tumor promotion activity. In our initial proteomic studies, the 14-3-3 protein that was found to be an RKIP-interacting protein was $14-3-3 \varepsilon$. The overexpression of $14-3-3 \varepsilon$ in vitro can limitedly prompt the abnormal growth of renal tumor cells [41]; and the cleavage and translocation of 14-3-3 epsilon is significantly associated with the inhibition of colon cancer cell proliferation [42]. Further study on the function of $14-3-3 \varepsilon$ in the tumor signaling pathway would be warranted.

\section{Specificity of identified RKIP-interacting proteins}

Specificity is a key issue in this study. In order to rule out the nonspecific bound proteins, three experiment groups were designed as pcDNA3.1-RKIP-3xFLAG, pcDNA3.13xFLAG (blank-carrier) control group, and the blank control group. The targets in this study are RKIP and its interacting proteins. The blank-carrier control pcDNA3.13xFLAG without RKIP fusion is a good, effective, and comparable control because the relative literature [18-26] has been reported that 3xFLAG coupled its specifically effective antibodies is an efficient and high-performance system to purify flag-tagged protein and its interacting partners. In addition, the small size of the FLAG peptide tag is not likely to obscure other epitopes, domains, or alter function, secretion, or transport of the fusion protein, and affect the interaction of the fusion protein with its partners [18]. Meanwhile, the previous quantitative proteomics studies discovered that both of 14-3-3 protein and RKIP were differentially expressed proteins in gastric carcinoma tissues [3]; however, this 3XFLAG peptide tag experiment confirmed the interaction of RKIP with 14-3-3 protein.

\section{Conclusions}

In summary, the targeted RKIP-interacting proteins were analyzed with proteomic methods to address the molecular mechanisms and biological roles of RKIP in GC. A total of 72 RKIP-related proteins were identified. All of these 72 proteins were directly or indirectly related to RKIP. Three RKIP-interaction protein network diagrams were constructed with MiMI, the functional linage network, and Predictome to address the molecular pathways of the functional activities of RKIP. The interactions of RKIP with HSP90, 14-3-3 protein, and keratin were verified by co-immunoprecipitation and Western blot analyses. Studies on HSP90 and 14-3-3 proteins in the RAS/ RAF/MEK/ERK signaling pathways have been reported [34,35]. Those two proteins (HSP90 and 14-3-3e) have close relationships with this signal pathway and with the transferring and activation of RAF-1. HSP90 and 14-3-3e were also associated with the growth and differentiation process of GC. Because these two specific proteins are involved in the mechanisms by which RKIP inhibits GC development, HSP90 and $14-3-3 \varepsilon$ proteins can consider as early-stage biomarkers and targets for therapeutic strategies to treat $\mathrm{GC}$.

\section{Additional files}

Additional file 1: Table S1. MS/MS identification of proteins that interact with RKIP.

Additional file 2: Table S2. MS/MS spectra of the corresponding peptides identifying three validated RKIP-interacting proteins.

\section{Competing interests}

The authors declare that they have no competing interests.

\section{Authors' contributions}

HG conceived, designed and carried out the work that led to the submission, and played an important role in interpreting the results. XZ was involved in drafting the manuscript and revising it critically for important intellectual content,and also played an important role in interpreting the results, approving the final version and corresponding. GZ participated in its design, coordination and corresponding and approved the final version. LY carried out the data collection and participated in the analysis of mass spectrometry. WCSC participated in revising it critically for important intellectual content. ML carried out the MS/MS-identification of proteins. TL participated in the purification of RKIP fusion proteins. ZC participated in its design and proteomics data explanation. All authors read and approved the final manuscript.

\section{Acknowledgments}

The work was supported by the National Natural Science Foundation of China (Grant No. 81072038), Development and Reform Commission of Hunan Province ([2010]1060), China Hunan Provincial Science and Technology Department (2009JT1010), the National Basic Research Program of China (Grant No. 2011CB910704), the National Natural Science Foundation of China (Grant No. 81272798 to X.Z.), and the Xiangya Hospital Funds for Talent Introduction (to X.Z.)

\section{Author details}

'Department of Gastroenterology, Xiangya Hospital, Central South University, Changsha, Hunan 410008, China. ${ }^{2}$ Key Laboratory of Cancer Proteomics of Chinese Ministry of Health, Xiangya Hospital, Central South University, Changsha, Hunan 410008, China. ${ }^{3}$ Department of Clinical Oncology, Queen Elizabeth Hospital, Hong Kong, China. 
Received: 10 June 2013 Accepted: 5 November 2013

Published: 9 November 2013

\section{References}

1. Katherine DC, Alfred IN: Epidemiology of gastric cancer. World J Gastroenterol 2006, 12:354-362.

2. Fox JG, Wang TC: Inflammation, atrophy, and gastric cancer. J Clin Invest 2007, 117:0-9.

3. Zhang ZQ, Li MY, Zhang GY, Peng F, Yao HX, Xiao ZQ, Chen ZC: Identification of human gastric carcinoma biomarkers by differential protein expression analysis using ${ }^{18} \mathrm{O}$ labeling and NanoLC-MS/MS coupled with laser capture microdissection. Med Oncol 2010, 27:296-303.

4. Jia $B Q$, Liu H, Kong Q, Li B: RKIP expression associated with gastric cancer cell invasion and metastasis. Tumor Biol 2012. doi:10.1007/ s13277-012-0317-3.

5. Trakul N, Rosner MR: Modulation of the MAP kinase signaling cascade by Raf kinase inhibitory protein. Cell Res 2005, 15:19-23.

6. Zhang ZQ, Zhang GY, Li MY, Liu T: Expression of Raf kinase inhibitor protein in human gastric cancer and its clinical significance. Chin J Dig 2009, 5:312-316

7. Fu Z, Smith PC, Zhang LZ, Rubin MA, Dunn RL, Yao Z, Keller ET: Effects of Raf kinase inhibitor protein expression on suppression of prostate cancer metastasis. J Natl Cancer Inst 2003, 95:878-889.

8. Keller ET, Brennan M: The biology of a prostate cancer metastasis suppressor protein: Raf kinase inhibitor protein. J Cell Biochem 2005, 94:273-278.

9. Keller ET: Role of Raf Kinase Inhibitor Protein in Pathophysiology of Prostate Cancer. Immunopathol Dis Therap 2011, 2:89-94.

10. Dabbous MK, Jefferson MM, Haney L, Thomas EL: Biomarkers of metastatic potential in cultured adenocarcinoma clones. Clin Exp Metastasis 2011, 28:101-111.

11. Schuierer MM, Heilmeier U, Boettcher A, Ugocsai P, Bosserhoff AK, Schmitz $\mathrm{G}$, Langmann T: Induction of Raf kinase inhibitor protein contributes to macrophage differentiation. Biochem Biophys Res Commun 2006 342:1083-1087.

12. Park S, Yeung ML, Beach S, Shields JM, Yeung KC: RKIP downregulates B-Raf kinase activity in melanoma cancer cells. Oncogene 2005, 24:3535-3540.

13. Zlobec I, Baker K, Minoo P, Jass JR, Terracciano L, Lugli A: Node-negative colorectal cancer at high risk of distant metastasis identified by combined analysis of lymph node status, vascular invasion, and Raf-1 kinase inhibitor protein expression. Clin Cancer Res 2008, 14:143-148.

14. Beshir AB, Ren G, Magpusao AN, Barone LM, Yeung KC, Fenteany G: Raf kinase inhibitor protein suppresses nuclear factor-kB-dependent cancer cell invasion at the level of matrix metalloproteinase expression but not cell migration. Cancer Lett 2010, 299:137-149.

15. Hagan S, Al-Mulla F, Mallon E, Oien K, Ferrier R, Gusterson B, Garcia C, Kolch W: Reduction of Raf-1 kinase inhibitor protein expression correlates with bread cancermetastasis. Clin Cancer Res 2005, 11:7392-3797.

16. Beshir AB, Argueta CE, Menikarachchi LC, Gascon JA, Genteany G: Locostatin disrupts association of Raf kinase inhibitor protein with binding proteins by modifying a conserved histidine residue in the ligand-binding pocket. Immunopathol Dis Therap 2011, 2:47-58.

17. Tavel L, Jaquillard L, Karsisiotis Al, Saab F, Jouvensal L, Brans A, Delmas AF, Schoentgen F, Cadene M, Damblon C: Ligand binding study of human PEBP1/RKIP: Interaction with nucleotides and Raf- 1 peptides evidenced by NMR and mass spectrometry. PLoS One 2012, 7:e36187.

18. FLAG and 3xFLAG overiew-A proven system for detection and purification of proteins. http://www.sigmaaldrich.com/content/dam/sigma-aldrich/ articles/biology/cloning-and-expression-flag-and-3xflag/flag-and-3x-flagoverview.pdf.

19. Ueda M, Manabe Y, Mukai M: The high performance of 3XFLAG for target purification of a bioactive metabolite: a tag combined with a highly effective linker structure. Bioorganic Med Chem Lett 2011, 21:1359-1362.

20. Zheng S, Ghitani N, Blackburn JS, Liu JP, Zeitlin SO: A series of N-terminal epitope tagged Hdh knock-in alleles expressing normal and mutant huntingtin: their application to understanding the effect of increasing the length of normal huntingtin's polyglutamine stretch on CAG140 mouse model pathogenesis. Mol Brain 2012, 5:28.

21. Macleod G, Varmuza S: Tandem affinity purification in transgenic mouse embryonic stem cells identifies DDOST as a novel PPP1CC2 interacting protein. Biochemistry 2012. in press.

22. Qu Y, Misaghi S, Izrael-Tomasevic A, Newton K, Gilmour LL, Lamkanfi M, Louie S, Kayagaki N, Liu J, Kömüves L, Cupp JE, Arnott D, Monack D, Dixit VM: Phosphorylation of NLRC4 is critical for inflammasome activation. Nature 2012, 490:539-542.

23. Dey A, Seshasayee D, Noubade R, French DM, Liu J, Chaurushiya MS, Kirkpatrick DS, Pham VC, Lill JR, Bakalarski CE, Wu J, Phu L, Katavolos P, LaFave LM, Abdel-Wahab O, Modrusan Z, Seshagiri S, Dong K, Lin Z, Balazs M, Suriben R, Newton K, Hymowitz S, Garcia-Manero G, Martin F, Levine RL, Dixit VM: Loss of the tumor suppressor BAP1 causes myeloid transformation. Science 2012, 337:1541-1546.

24. Lee H, Park M, Shin N, Kim G, Kim YG, Shin JS, Kim H: High mobility group box-1 is phosphorylated by protein kinase $C$ zeta and secreted in colon cancer cells. Biochem Biophys Res Commun 2012, 424:321-326.

25. Aichem A, Groettrup M: Detection and analysis of FAT10 modification. Methods Mol Biol 2012, 832:125-132.

26. Cardenal-Muñoz E, Ramos-Morales F: Analysis of the expression, secretion and translocation of the Salmonella enterica type III secretion system effector SteA. PLoS One 2011, 6:e26930.

27. Adlard PA, Bush AL: Metals and Alzheimer's disease. J ALzheimers Dis 2006, 10:145-163.

28. Nichols A, Camps M, Gillieron C, Chabert C, Brunet A, Wilsbacher J, Cobb M, Pouyssegur J, Shaw JP, Arkinstall S: Substrate recognition domains within extracellular signal-regulated kinase mediate binding and catalytic activation of mitogen-activated protein kinase phosphatase-3. J Biol Chem 2000, 275:24613-24621.

29. Liang SL, He LJ, Zhao XD, Miao Y, Gu Y, Guo CC, Xue ZF, Dou WJ, Hu FR, Wu KC, Nie YZ, Fan DM: MicroRNA Let-7f inhibits tumor invasion and metastasis by targeting MYH9 in human gastric cancer. PLOS One 2011, 6:e18409.

30. Walch A, Seidl S, Hermannstadter C: Combined analysis of Racl, IQGAP, Tiaml and E-cadherin expression in gastric cancer. Mod Pathol 2008, 21:544-552.

31. Yu GZ, Wang JJ, Chen Y, Wang X, Pan J, Li Q, Xie KP: Tissue microarray analysis reveals strong clinical evidence for a close association between loss of annexin A1 expression and nodal metastasis in gastric cancer. Clin Exp Metastasis 2008, 25:695-702.

32. Chen CD, Wang CS, Huang YH, Chien KY, Liang Y, Chen WJ, Lin KH: Overexpression of CLIC1 in human gastric carcinoma and its clinicopathological significance. Proteomics 2007, 7:155-167.

33. Zhang Y, Qu X, Jing W, Hu X, Yang X, Teng K, Zhang J, Liu Y: GSTP1 determines cis-platinum cytotoxicity in gastric adenocarcinoma MGC803 cell: regulation by promoter methylation and extracellular regulated kinase signaling. Anticancer Drugs 2009, 20:208-214.

34. Yu X, Guo ZS, Marcu MG, Neckers L, Nguyen DM, Chen GA, Schrump DS: Modulation of p53, ERbB1, ERbB2, and Raf-1 expression in lung cancer cells by depsipeptide FR901228. J Nat Cancer Inst 2002, 94:504-513.

35. Fu H, Subramanian RR, Masters SC: 14-3-3 proteins: structure, function, and regulation. Ann Rev Pharmacol Toxicol 2000, 40:617-647.

36. Liu X, Ye L, Wang J, Fan D: Expression of heat shock protein 90 in human gastric cancer tissue and SGC7901/NCR of MDR-type gastric cancer cell line. Chin Med J 1999, 112:1133-1137.

37. Kuramitsu Y, Baron B, Yoshino S, Zhang X, Tanaka T, Yashiro M, Hirakawa K, Oka M, Nakamura K: Proteomic differential display analysis shows upregulation of 14-3-3 sigma protein in human scirrhous-type gastric carcinoma cells. Anticancer Res 2010, 30:4459-4465.

38. Jaqietto E, Krasnowska M: The role of genetic factors, apoptosis and 14-3-3 protein in induction of atopic diseases. Postepy Hiq Med Dosw 1997, 51:385-398.

39. Thorson JA, Yu LW, Hsu AL, Shih NY, Graves PR, Tanner JW, Allen PM, Piwnica-Worms $H$, Shawl AS: 14-3-3 proteins are required for maintenance of Raf-1 phosphorylation and kinase activity. Mol Cell Biol 1998, 8:529-538.

40. Zuo S, Xue Y, Tang SW, Yao J, Du D, Yang P, Chen X: 14-3-3 epsilon dynamically interacts with key components of mitogen-activated protein 
kinase signal module for selective modulation of the TNF-a-induced time course-dependent NF- $\gamma B$ activity. J Proteome Res 2010, 9:3465-3478.

41. Liang S, Xu Y, Shen G, Liu Q, Zhao X, Xu Z, Xie X, Gong F, Li F, Li R, Wei Y: Quantitative protein expression profiling of 14-3-3 isoforms in human renal carcinoma shows 14-3-3 epsilon is involved in limitedly renal cell proliferation. Electrophoresis 2009, 30:4152-4162.

42. Liu Y, Song F, Wu WKK, He M, Zhao L, Sun X, Li H, Jiang Y, Yang Y, Peng K: Triptolide inhibits colon cancer cell proliferation and induces cleavage and translocation of 14-3-3 epsilon. Cell Biochem Funct 2012. doi:10.1002/ cbf.2793.

doi:10.1186/1471-2407-13-536

Cite this article as: Gu et al:: Mapping the interactome of overexpressed RAF kinase inhibitor protein in a gastric cancer cell line. BMC Cancer 2013 13:536.

\section{Submit your next manuscript to BioMed Central and take full advantage of:}

- Convenient online submission

- Thorough peer review

- No space constraints or color figure charges

- Immediate publication on acceptance

- Inclusion in PubMed, CAS, Scopus and Google Scholar

- Research which is freely available for redistribution 